\title{
Niedosłuch wywoływany przez mutacje w mitochondrialnym DNA
}

\section{Hearing loss caused by mutations in mitochondrial DNA}

\author{
Urszula Lechowicz, Agnieszka Pollak, Monika Ołdak
}

Instytut Fizjologii i Patologii Słuchu, Światowe Centrum Słuchu, Zakład Genetyki, Warszawa/Kajetany

Adres autora: Monika Ołdak, Światowe Centrum Słuchu, Zakład Genetyki, ul. Mokra 17, Kajetany, 05-830 Nadarzyn, e-mail: m.oldak@ifps.org.pl

\section{Streszczenie}

Wprowadzenie: Utrata słuchu jest często spotykanym schorzeniem, występującym przeważnie jako jedyny (izolowany) objaw u pacjenta. $\mathrm{W}$ większości przypadków za wystąpienie niedosłuchu izolowanego odpowiadają mutacje w układzie dziedziczenia autosomalnym recesywnym (ok. 80\%), rzadziej autosomalnym dominujący (ok. 20\%), sprzężonym z chromosomem X lub matczynym, który jest powiązany z mutacjami w genomie mitochondrialnym (ok. 1\%).

Cel pracy: Dotychczas w piśmiennictwie polskim ukazało się niewiele opracowań na temat mutacji w mitochondrialnym DNA (mtDNA) powodujących niedosłuch, w związku z tym w niniejszej pracy przedstawiono aktualny stan wiedzy w tej dziedzinie, skupiając się przede wszystkim na mutacjach mtDNA związanych z występowaniem niedosłuchu izolowanego.

Materiał i metody: Analiza danych literaturowych dotyczących mutacji w mitochondrialnym DNA odpowiadających za wystąpienie niedosłuchu.

Wyniki i wnioski: Mutacje w mitochondrialnym DNA nie sa wprawdzie czesta przyczyna utraty słuchu, ale w diagnostyce tego schorzenia należy rozważyć badanie w kierunku mutacji mitochondrialnego DNA, zwłaszcza u pacjenta z niedosłuchem obustronnym, symetrycznym, postępującym w czasie, początkowo występującym tylko w obrębie wysokich tonów, a następnie zajmującym również inne częstotliwości, który występuje rodzinnie i cechuje się matczynym dziedziczeniem.

Słowa kluczowe: niedosłuch • genom mitochondrialny • mutacje $\bullet$ mtDNA

Abstract

Introduction: Hearing loss is a very common disorder, often occurring as the only (isolated) symptom in patients. In most cases, isolated hearing loss is inherited in an autosomal recessive (app. 80\%), autosomal dominant (app. 20\%) or X-linked manner or matrilineally as a result of mutations in the mitochondrial genome (app. 1\%).

Objective: There are only a few studies in Polish literature on mutations in mitochondrial DNA (mtDNA) causing hearing loss. This paper presents the current state of knowledge in this field and focuses primarily on mtDNA mutations leading to isolated hearing loss.

Material and methods: Literature review on mitochondrial DNA mutations, responsible for the occurrence of hearing loss.

Results and conclusions: Mutations in the mitochondrial DNA, might not be a common cause of hearing loss, but they should be considered in the diagnostic process, especially when the patient suffers from bilateral, symmetrical and progressive hearing loss that initially affects high frequencies and then spreads to other frequencies and is characterized by a maternal mode of inheritance.

Key words: hearing loss $\bullet$ mitochondrial genome $\bullet$ mutations $\bullet$ mtDNA 


\section{Wprowadzenie}

Według danych Światowej Organizacji Zdrowia (World Health Organization, WHO) utrata słuchu jest często spotykanym schorzeniem, które dotyczy około $5 \%$ populacji świata (360 mln osób). W przeważającej części przypadków niedosłuch to jedyny (izolowany) objaw występujący u pacjenta, ale mogą mu również towarzyszyć inne objawy, tworząc złożone zespoły chorobowe. Wczesne wykrycie wady słuchu ma kluczowe znaczenie w ograniczaniu negatywnych skutków, jakie niedosłuch wywiera na rozwój mowy, adaptację społeczną oraz jakość życia [1,2].

Ponad 50\% wrodzonych wad słuchu ma podłoże genetyczne. Najczęściej za występowanie niedosłuchu izolowanego odpowiadają mutacje w układzie dziedziczenia autosomalnym recesywnym (ok. $80 \%$ przypadków), choć nie należy zapominać również o niedosłuchu dziedziczonym w sposób autosomalny dominujący (ok. 20\% przypadków), sprzężonym $\mathrm{z}$ chromosomem $\mathrm{X}$ lub powiązanym $\mathrm{z}$ mutacjami w genomie mitochondrialnym (ok. 1\% przypadków) [3].

W niniejszym opracowaniu przedstawiony zostanie aktualny stan wiedzy o wybranych mutacjach w genomie mitochondrialnym, będących przyczyną wystąpienia niedosłuchu izolowanego.

\section{Mitochondria - budowa i funkcje}

W większości ludzkich komórek znajduje się od kilkuset do kilku tysięcy mitochondriów, przyjmujących różnorodne kształty i rozmiary. Mitochondria otoczone są dwiema błonami białkowo-lipidowymi, różniącymi się od siebie właściwościami. Błona zewnętrzna otacza całe organellum, jednocześnie nadając mu kształt oraz oddzielając je od środowiska zewnętrznego. Błona wewnętrzna tworzy wpuklenia w postaci fałdów (tzw. grzebienie), mających za zadanie zwiększyć jej powierzchnię. Wewnątrz mitochondrium, czyli w macierzy ograniczonej błoną wewnętrzną, znajduje się roztwór zawierający białka, metabolity, rybosomy mitochondrialne oraz genom mitochondrialny $[4,5]$.

Mitochondria odpowiadają za dostarczanie energii komórce poprzez proces fosforylacji oksydacyjnej, przebiegający dzięki wyspecjalizowanym kompleksom białkowym tworzącym mitochondrialny łańcuch transportu elektronów. Energia chemiczna wytwarzana jest w postaci wysokoenergetycznych wiązań adenozynotrifosforanu (ATP). Podczas syntezy ATP zachodzącej w mitochondriach powstają również reaktywne formy tlenu (RFT), które są normalnymi produktami ubocznymi tego procesu, tym niemniej ich nadprodukcja może prowadzić do istotnego zaburzenia funkcjonowania mitochondriów, a w konsekwencji do ich śmierci w mechanizmie samobójczym (tzw. mitoptozy) [6]. Mitochondria pełnią również kluczową funkcję w programowanej śmierci komórki (apoptozie), kontroli poziomu RFT, cyklu mocznikowym (dotyczy komórek wątroby), $\beta$-oksydacji kwasów tłuszczowych oraz w procesie odpowiedzialnym za zachowanie równowagi wapniowej komórki $[7,8]$. Poprzez wewnętrzną organizację komórkową mitochondria mogą oddziaływać $\mathrm{z}$ innymi organellami (np. jądrem komórkowym), zapewniając wysoki poziom łączności i plastyczności, ułatwiających ich funkcjonowanie w komórce.

\section{Genom mitochondrialny - zjawisko homo-} i heteroplazmii oraz dziedziczenie

W każdym mitochondrium znajduje się materiał genetyczny w postaci kilku kopii kolistych, dwuniciowych cząsteczek kwasu deoksyrybonukleinowego (DNA) o długości 16659 par zasad (pz), co uzasadnia określanie tych organelli semiautonomicznymi. Genom mitochondrialny zawiera 13 genów kodujących peptydy będące składowymi łańcucha oddechowego, 22 geny kodujące transportujący kwas rybonukleinowy (tRNA) oraz dwa geny odpowiedzialne za syntezę rybosomalnego RNA (rRNA). Ze względu na różnicę w zawartości zasad purynowych i pirymidynowych wyróżnia się nić ciężką $\mathrm{H}$ (ang. heavy ciężka) i lekką L (ang. light - lekka). Geny leżą na obydwu niciach, przy czym 28 z nich znajduje się na nici ciężkiej, a pozostałe na nici lekkiej. Do prawidłowego funkcjonowania mitochondrium niezbędne są produkty białkowe kodowane przez geny jądrowe $[9,10]$. Białka kodowane w DNA jądrowym ulegają translacji w cytoplazmie i są importowane do wnętrza mitochondrium [11].

\section{Heteroplazmia}

W każdej komórce znajduje się od kilkuset do kilku tysięcy mitochondriów, a w nich po kilka kopii mtDNA, które mogą różnić się od siebie składem nukleotydowym. Stan, w którym wszystkie cząsteczki mtDNA są identyczne, określa się jako homoplazmię, natomiast gdy obserwuje się współistnienie mtDNA o prawidłowej (kanoniczej) sekwencji oraz cząsteczek mtDNA z wariantami nukleotydowymi, takie zjawisko określa się terminem heteroplazmia (rycina 1). Uważa się, że tkanki spełniają prawidłowo swoje funkcje, dopóki poziom zmutowanego DNA mitochondrialnego nie przekroczy pewnej wartości progowej, która nie jest stała i zależy od wielu różnych czynników, m.in. od typu występującej mutacji oraz rodzaju tkanki, której zjawisko to dotyczy. Wyzwaniem diagnostycznym w przypadku zmian zlokalizowanych w genomie mitochondrialnym jest określenie stopnia heteroplazmii, który może zawierać się w przedziale pomiędzy 0 a $100 \%[12,13]$. Dla porównania identyfikacja zmian konstytucyjnych w jądrowym DNA odbywa się układzie 0/1 (mutacja występuje bądź nie).

\section{Dziedziczenie mtDNA}

Mitochondria dziedziczone są wyłącznie w linii matczynej. W trakcie podziału komórki mitochondria i ich genomy segregowane są w sposób losowy do komórek potomnych. Może prowadzić to do znacznych różnic w poziomie heteroplazmii między komórkami jajowymi (oocytami), a w konsekwencji do odmiennego poziomu heteroplazmii wśród potomstwa $[13,14]$.

\section{Mutacje mtDNA}

Genom mitochondrialny istotnie różni się od genomu jądrowego. Jedną z tych odmienności jest brak procesu rekombinacji pomiędzy cząsteczkami mtDNA oraz znacznie wyższa częstość spontanicznych mutacji w porównaniu $\mathrm{z}$ jądrowym DNA. Występowanie spontanicznych mutacji w mtDNA związane jest $\mathrm{z}$ brakiem systemów naprawczych, brakiem histonów oraz narażeniem na bezpośrednie 


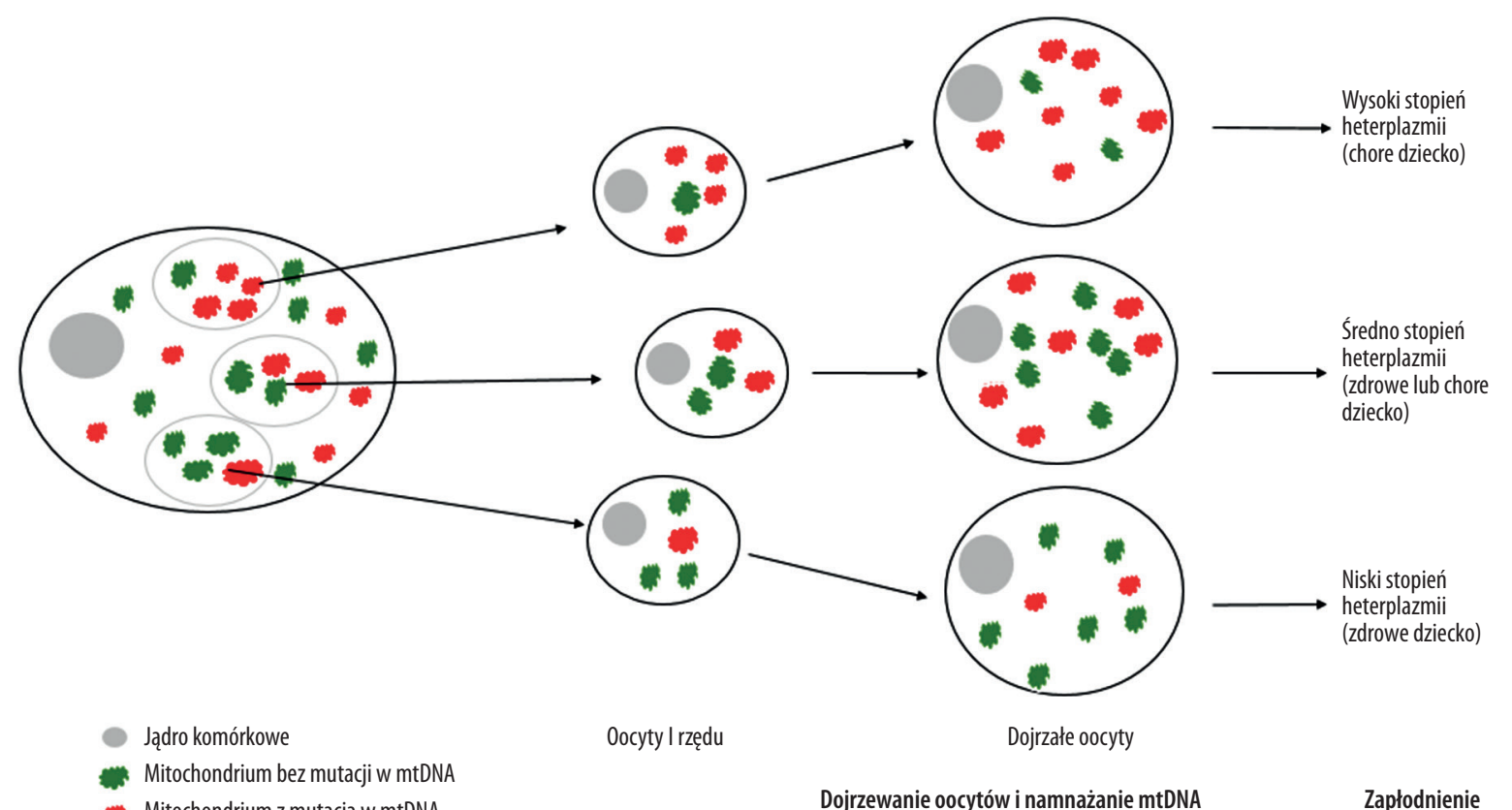

Rycina 1. Losowa segregacja mitochondriów w czasie powstawania oocytów, tzw. mitochondrialne wąskie gardło Figure 1. Random segregation of mitochondria during oocyte maturation, so called "mitochondrial bottleneck"

działanie wolnych rodników tlenowych powstających podczas syntezy ATP. RFT są wysoce toksycznymi i reaktywnymi cząsteczkami z niesparowanymi elektronami, które mogą się łączyć z innymi związkami, prowadząc do poważnych dysfunkcji komórkowych. Uszkodzenia oksydacyjne spowodowane przez RFT określa się mianem stresu oksydacyjnego.

Większość zmian w genomie mitochondrialnym stanowią mutacje punktowe. Uważa się, że z wiekiem liczba mutacji mtDNA ulega akumulacji. Defektywne mitochondria nie produkują wystarczającej ilości energii. W odpowiedzi na spadek poziomu energetycznego zwiększa się tempo podziału mitochondriów, kompensując stratę energetyczną, ale jednocześnie powodując generowanie większej liczby organelli z defektami nukleotydowymi w obrębie mtDNA. Nieprawidłowe mitochondria produkują istotnie więcej wolnych rodników tlenowych, inicjując kaskadę generowania kolejnych mutacji w genomie mitochondrialnym $[15,16]$.

\section{Choroby mitochondrialne}

Warianty nukleotydowe skutkujące zaburzeniem funkcjonowania mitochondriów mogą przyczyniać się do patologii ogólnoustrojowych w postaci różnych jednostek chorobowych, takich jak MELAS (miopatia mitochondrialna, encefalopatia, kwasica mleczanowa, występowanie incydentów udaropodobnych, ang. mitochondrial myopathy, encephalopathy, lactic acidosis, stroke-like episodes) [17-19], LHON (dziedziczna neuropatia wzrokowa Lebera, ang. Leber's hereditary optic neuropathy), zespół MIDD (cukrzyca i niedosłuch czuciowo-nerwowy, ang. maternally inherited diabetes-deafness syndrome), MERRF (padaczka miokloniczna z czerwonymi poszarpanymi włókna$\mathrm{mi}$, ang. myoclonic epilepsy with ragged red fibers) [20], zespół Leigha [21].
MELAS to jeden z najczęściej występujących spośród wyżej wymienionych zespołów, jego przyczynę upatruje się $\mathrm{w}$ nieprawidłowym funkcjonowaniu mitochondriów, zwykle spowodowanym przez mutację w pozycji 3243 (m.3243A >G) w genie MT-TL1, kodującym tRNA leucyny, którą identyfikuje się u $80 \%$ chorych. Jednym z często obserwowanych objawów towarzyszących temu zespołowi jest niedosłuch $[17,19]$. Mutacja m.3243A $>$ G może prowadzić do niedosłuchu izolowanego albo niedosłuchu i cukrzycy. U ok. $10 \%$ osób z tą mutacją może wystąpić kardiomiopatia. Heterogenność objawów spowodowana konsekwencjami mutacji m.3243A>G jest przykładem bardzo charakterystycznej dla mutacji mitochondrialnych ogromnej różnorodności fenotypowej.

Występujące w mtDNA delecje związane są z różnymi jednostkami klinicznymi, takimi jak zespół Pearsona [22], przewlekła postępująca zewnętrzna oftalmoplegia (CPEO, ang. chronic progressive external ophtalmoplegia) [23] i zespół Kearnsa-Sayre’a [24].

Mutacje mtDNA mogą być także przyczyną wystąpienia izolowanych objawów takich jak niska ruchliwość plemników, retinopatia, cukrzyca czy niedosłuch [25-27]. To RFT generowane przez mitochondria mogą być inicjatorami wystąpienia niedosłuchu w różnorodnym mechanizmie, m.in. po ekspozycji na antybiotyki aminoglikozydowe [28] lub hałas (ang. noise induced hearing loss, NIHL) [29,30]. RFT odpowiedzialne są również za ubytek słuchu związany z wiekiem (ang. age-related hearing loss, ARHL) [31] oraz są przyczyną wystąpienia niedosłuchu izolowanego.

\section{Mutacje mtDNA a niedosłuch}

Charakterystyczną cechą mutacji w mtDNA jest duża niejednorodność objawów klinicznych, czego 
Tabela 1. Mutacje w mtDNA powodujące wystąpienie niedosłuchu syndromicznego

Table 1. Mutations in mtDNA leading to syndromic hearing loss

\begin{tabular}{llll}
\hline Gen & \multicolumn{1}{c}{ Mutacja } & \multicolumn{1}{c}{ Fenotyp } & Źródto \\
\hline MT-TL1 & m.3243A>G & MELAS oraz MIDD & {$[34,35]$} \\
\hline \multirow{2}{*}{ MT-TK } & m.8344A>G & MERRF & {$[36]$} \\
\cline { 2 - 4 } & m.8356T>C & MIDD & {$[37]$} \\
\hline MT-TS1 & m.7512T>C & postępująca miokloniczna padaczka, ataksja & {$[38]$} \\
\hline Różne geny & duże delecje & i niedosłuch & {$[39]$} \\
\hline Różne geny & duże delecje/duplikacje & MIDD & {$[23]$} \\
\hline MT-TE & m.14709T>C & MIDD & {$[41]$} \\
\hline
\end{tabular}

Tabela 2. Mutacje w mtDNA odpowiedzialne za wystąpienie niedosłuchu izolowanego

Table 2. Mutations in mtDNA leading to isolated hearing loss

\begin{tabular}{|c|c|c|c|}
\hline Gen & Mutacja & Sporadycznie współwystępujące objawy & Źródło \\
\hline \multirow{3}{*}{ MT-RNR1 } & m.1555A>G & \multirow{3}{*}{$\begin{array}{l}\text { podanie antybiotyków aminoglikozydowych } \\
\text { pogłębia niedosłuch }\end{array}$} & {$[42-44]$} \\
\hline & m.1494T>C & & [45] \\
\hline & m.961 (różne mutacje) & & {$[46,47]$} \\
\hline \multirow{4}{*}{ MT-TS1 } & $\mathrm{m} .7445 \mathrm{~A}>\mathrm{G}$ & rogowacenie dłoni i stóp & {$[48-50]$} \\
\hline & m.7472insC & zaburzenia neurologiczne & {$[51-53]$} \\
\hline & m.7510T>C & \multirow{2}{*}{ brak dodatkowych objawów } & [54] \\
\hline & $\mathrm{m} .7511 \mathrm{~T}>\mathrm{C}$ & & {$[55,56]$} \\
\hline
\end{tabular}

odzwierciedleniem są obserwowane u nosicieli tej samej zmiany różnice w czasie ujawnienia się niedosłuchu, stopniu upośledzenia słuchu czy jego progresji. Jednakże obecność mutacji nie jest jedynym czynnikiem determinującym manifestację kliniczną, ponieważ wśród nosicieli tego samego wariantu są osoby nieobciążone wadą słuchu. Liczne badania wskazują również, że poziom penetracji mutacji mitochondrialnych modulowany jest przez dodatkowe czynniki, takie jak oddziaływanie genów jądrowych, haplotyp mitochondrialny czy też czynniki środowiskowe. Analiza całej sekwencji mtDNA pozwoliła na wskazanie tzw. gorących miejsc mutacji, które warunkują niedosłuch izolowany i które w ogromnej większości identyfikowane są w genach MT-RNR1 oraz MT-TS1. Najczęściej mutacje $\mathrm{w}$ mitochondrialnym DNA związane $\mathrm{z}$ ubytkiem słuchu występują w postaci homoplazmatycznej i są przyczyną niedosłuchu postlingwalnego, obustronnego i symetrycznego, który może postępować w czasie. Istnieje ogromna różnorodność w głębokości niedosłuchu wśród badanych rodzin $\mathrm{z}$ tym samym defektem nukleotydowym mtDNA. $\mathrm{W}$ wielu przypadkach wraz $\mathrm{z}$ niedosłuchem występują szumy uszne i/lub zawroty głowy [32]. Uważa się, że nawet $5 \%$ izolowanych, postlingwalnych przypadków niedosłuchu może być spowodowanych mutacjami w mtDNA $[32,33]$. Mutacje powiązane $\mathrm{z}$ wystąpieniem niedosłuchu zarówno syndromicznego, jak i izolowanego przedstawiono odpowiednio w tabelach 1 i 2 .
Mutacje w genie $M T-R N R 1: \mathrm{m} .1555 \mathrm{~A}>\mathrm{G}$, m.1494C $>$ T oraz m.961 - różne warianty

Gen MT-RNR1 koduje mitochondrialny 12S rRNA, (rybosomalny kwas rybonukleinowy), wchodzący w skład rybosomów, które są konieczne do syntezy białek. Mutacje w genie MT-RNR1 najczęściej powiązane są z wystąpieniem niedosłuchu izolowanego bądź niedosłuchu występującego po ekspozycji na aminoglikozydy. Celem dla antybiotyków aminoglikozydowych jest region 16S rRNA bakterii Gram-ujemnych. Miejsce to jest analogiczne do ludzkiego rejonu mtDNA kodującego podjednostkę $12 \mathrm{~S}$ rRNA. Antybiotyki aminoglikozydowe są często podawane w leczeniu zagrażających życiu zakażeń bakteriami Gram-ujemnymi, jednak ich stosowanie jest kontrowersyjne ze względu na ich szkodliwy wpływ na nerki oraz właściwości ototoksyczne [57]. Do leków tej klasy należą m.in amikacyna, streptomycyna, gentamycyna, tobramycyna, neomycyna. Nefrotoksyczność wywołana aminoglikozydami jest odwracalna, w odróżnieniu od ototoksyczności spowodowanej podaniem tych antybiotyków. Niedosłuch jest powikłaniem występującym u ok. 25\% pacjentów leczonych aminoglikozydami $[57,58]$.

Jedną z częściej identyfikowanych mutacji w genomie mitochondrialnym, powiązaną z niedosłuchem izolowanym i/lub ujawniającym się po podaniu leków aminoglikozydowych, 
A

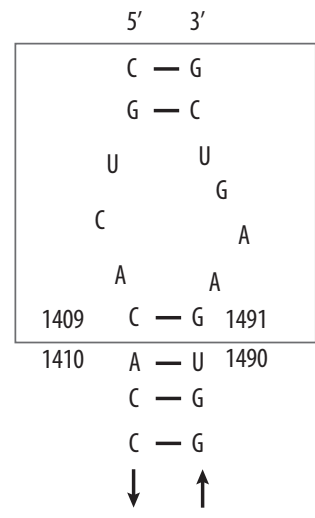

Fragment bakteryjnego 165 rRNA

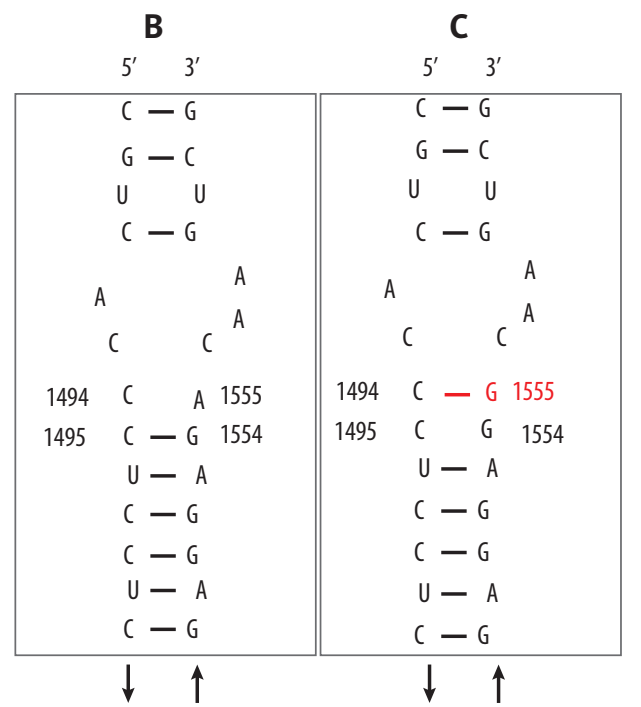

Fragment prawidłowego ludzkiego 125 rRNA

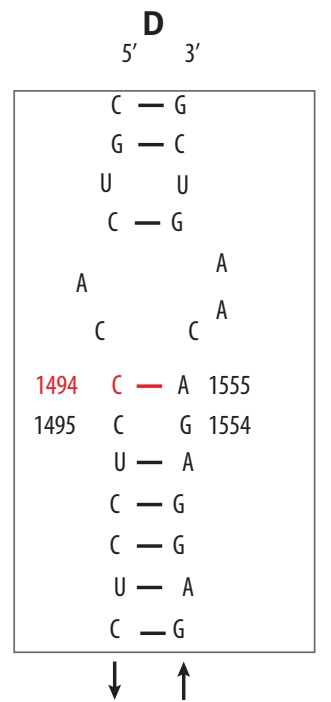

Fragment 125 rRNA z mutacją m.1494C >U

Rycina 2. Schemat fragmentu struktury II-rzędowej 16S rRNA E. coli (A), ludzkiego 12S rRNA powstający z prawidłowej sekwencji mtDNA (B) oraz z mtDNA zawierającego mutacje m.1555A>G oraz m.1494C>T (C i D); w sekwencji RNA zamiast tyminy (T) występuje uracyl (U); ramka pokazuje miejsce przyłączenia antybiotyku aminoglikozydowego

Figure 2. Fragment of secondary structure of E. coli $16 \mathrm{~S}$ rRNA (A), the human $12 \mathrm{~S}$ rRNA sequence transcribed from wild type mtDNA (B) and the mtDNA sequence with m.1555A>G and m.1494C>T mutations (C and D); in the RNA sequence instead of thymine $(\mathrm{T})$ is uracil $(\mathrm{U})$; the frame shows the position where aminoglycosides attach to mtDNA

jest homoplazmatyczna mutacja m.1555A > G, zlokalizowana w genie $M T-R N R 1$. Występuje ona ze średnią częstością ok. 1-3,6\% wśród osób z niedosłuchem z populacji polskiej. Dla pacjentów $\mathrm{z}$ wariantem $\mathrm{m}$.1555A $>\mathrm{G}$ charakterystyczny jest niedosłuch typu wysokotonowego [18,59], określany również jako partial deafness (PD) [60].

Do chwili obecnej nie został w pełni wyjaśniony mechanizm wywoływania przez aminoglikozydy niedosłuchu w obecności wariantu m.1555A $>$ G i jednoczesnym braku wystąpienia uszkodzeń nerek. Może wynikać to z faktu, że głównym miejscem toksycznego działania aminoglikozydów jest prążek naczyniowy, który zawiera wysoce wyspecjalizowany, metabolicznie aktywny nabłonek bogaty $\mathrm{w}$ mitochondria, znajdujący się $\mathrm{w}$ ścianie bocznej przewodu ślimakowego [61]. Mutacja m.1555A $>$ G powoduje nieodwracalną zmianę konformacji 12S rRNA, skutkującą bardziej ścisłym wiązaniem aminoglikozydów niż w przypadku cząsteczki, w której mutacja nie występuje (rycina 2). Indukuje to błędy w syntezie białek [62]. W konsekwencji może więc powodować zaburzenia $\mathrm{w}$ funkcjonowaniu prążka naczyniowego, odpowiadającego za wytwarzanie potencjału wewnątrzślimakowego i utrzymanie wysokiego stężenia jonów potasu $\left(\mathrm{K}^{+}\right)$w endolimfie. Ponadto antybiotyki aminoglikozydowe dostają się do komórek słuchowych kanałami znajdującymi się na szczycie komórek słuchowych (ang. mechanotransducer channels, MET) lub na zasadzie endocytozy i preferencyjnie gromadzą się w mitochondriach, zaburzając jednocześnie syntezę białek mitochondrialnych w tych komórkach $[62,63]$. Wadliwa synteza białek mitochondrialnych może prowadzić do nieefektywnego działania łańcucha oddechowego, zaburzenia wytwarzania ATP i zwiększonego wytwarzania RFT, wywołując przejściową przepuszczalność błon mitochondrialnych i prowadząc do śmierci komórki na drodze apoptozy $[64,65]$. Spośród dwóch rodzajów komórek słuchowych bardziej podatne na działanie aminoglikozydów są komórki słuchowe zewnętrzne (ang. outer hair cel, OHCs) niż komórki słuchowe wewnętrzne (ang. inner hair cells, IHCs) [66-68]. Jednak dokładny mechanizm oddziaływania aminoglikozydów z rRNA nadal jest przedmiotem intensywnych badań [69].

Obserwuje się również niedosłuch u osób z mutacją m.1555A > G, którym nie były podawane leki aminoglikozydowe. Niemniej w takich przypadkach niedosłuch jest zazwyczaj mniej nasilony i ujawnia się w późniejszym wieku. Uważa się, że w takich rodzinach prawdopodobnie występuje dodatkowy modyfikator, powodujący utratę słuchu bez ekspozycji na aminoglikozydy [44].

W pozycji 1494 mitochondrialnego genu MT-RNR1 występuje inna mutacja uwrażliwiająca na działanie antybiotyków aminoglikozydowych. Mutacja m.1494C >T powoduje utworzenie nowego wiązania komplementarnego w pozycji 1494-1555 12S rRNA (rycina 2), czyli w analogicznej lokalizacji, gdzie znajduje się para CG powstająca w wyniku opisywanej wcześniej mutacji m.1555A $>$ G. W celu sprawdzenia, czy mutacja m.1494C $>$ T prowadzi do aminoglikozydowej toksyczności, wyprowadzono limfoblastyczne linie komórkowe pochodzące od sześciu członków chińskiej rodziny (w tym czterech osób z mutacją m. 1494C>T, u których wystąpił niedosłuch, i dwóch ze zidentyfikowaną mutacją m.1494C $>\mathrm{T}$, ale dobrze słyszących) oraz czterech osób bez mutacji m.1494C>T (linie kontrolne). Następnie analizowano wrażliwość linii na 
leki aminoglikozydowe i mierzono zdolność oddychania w poszczególnych liniach komórkowych przez określenie szybkości zużycia tlenu w komórkach. Badanie wykazało, iż linie komórkowe z mutacją m.1494C>T, w porównaniu z liniami komórek typu dzikiego, wykazywały znacząco niższe tempo wzrostu w obecności wysokiego stężenia paromomycyny i neomycyny, jak również obniżone tempo całkowitego zużycia tlenu $[45,70]$, potwierdzając toksyczność badanych związków również w układzie in vitro.

Wariantami powiązanymi z wystąpieniem niedosłuchu izolowanego lub po podaniu antybiotyków aminoglikozydowych są także różne mutacje w pozycji 961 genu $M T-R N R 1$, m.in. T>C, delT+C(n)ins, T>insC [59,71,72]. Jednak dane na temat tych zmian nie są jednoznaczne. Pojawiają się również opinie, iż są to niepatogenne polimorfizmy ze względu na ich podobną częstość występowania wśród niesłyszących pacjentów i w populacyjnej grupie kontrolnej. Elstner i wsp. wygenerowali komórki cybrydowe (cybrydy lub tzw. mieszańce cytoplazmatyczne to komórki posiadające jądro komórkowe pochodzące $\mathrm{z}$ jednego organizmu a cytoplazmę wraz $\mathrm{w}$ mitochondriami $\mathrm{z}$ innego - w tym wypadku $\mathrm{z}$ wariantem patogennym) ze zmianą m.961T >C i wykazali, iż nie było istotnych statystycznie różnic w produktach translacji pomiędzy komórkami kontrolnymi a komórkami z mutacją m.961T>C [73]. Zatem rola zmian zlokalizowanych w pozycji $961 \mathrm{w}$ patogenezie niedosłuchu pozostaje nadal niejasna.

\section{Mutacje w genie $M T-C O 1: \mathrm{m} .7445 \mathrm{~A}>\mathrm{G}$}

Gen MT-CO1 koduje podjednostkę I oksydazy cytochromu c (COX1), białka IV kompleksu łańcucha oddechowego zlokalizowanego w błonie mitochondrialnej [74].

Mutację m.7445A>G zidentyfikowano wśród niesłyszących członków rodzin ze Szkocji, Nowej Zelandii, Ukrainy, Japonii i Mongolii $[48,54,55,75,76]$. Mutacja m.7445A>G zlokalizowana jest w kodonie stop (AGA) mRNA kodującego podjednostkę I oksydazy cytochromu c na nici $\mathrm{H}$ i skutkuje powstaniem innego kodonu stop (AGG) [77]. Na Nici L pozycja 7445 przylega do 3' końca genu MT-TS1. W tym przypadku mutacja m.7445A $>$ G nie zmienia struktury tRNA transportującego serynę (tRNA $\left.{ }^{\mathrm{Ser}(\mathrm{UCN})}\right)$, wpływa natomiast na szybkość przetwarzania prekursorowego tRNA ${ }^{\text {Ser(UCN) }}$, powodując zmniejszenie poziomu tRNA ${ }^{\mathrm{Ser}(\mathrm{UCN})}$ oraz obniżony poziom mRNA dehydrogenazy 6 (ND6) i zmniejszoną syntezę białka (mRNA dla MT-ND6 i MT-TS1 pochodzą z tej samej cząsteczki prekursorów) $[48,78,79]$. Poza niedosłuchem w kilku rodzinach opisano wystąpienie mutacji $\mathrm{m} .7445 \mathrm{~A}>\mathrm{G} w$ połączeniu $\mathrm{z}$ rogowaceniem dłoni i stóp (palmoplantar keratodermia). Mutacja ta znajdowana jest zarówno w postaci homo- jak i heteroplazamtycznej, a stopień penetracji mutacji jest różnorodny [32]. Częstość występowania tej mutacji w populacji polskich pacjentów z niedosłuchem oszacowano na $0,4 \%$ (1/250). Pacjenci z mutacją m.7445A > G zazwyczaj cierpią z powodu obustronnej, postępującej utraty słuchu po podaniu aminoglikozydów [80].

\section{Mutacje w genie MT-TS1: m.7510T $>\mathrm{C}$} i $\mathrm{m} .7511 \mathrm{~T}>\mathrm{C}$

Mitochondrialnie tRNA ${ }^{\text {Ser(UCN) }}$ jest małym 69 nukleotydowym RNA, kodowanym przez gen MT-TS1, przenoszącym serynę do budowanego łańcucha polipeptydowego podczas procesu translacji. Mutacje m.7510T $>$ C i m.7511T $>C$ znajdujące się w części akceptorowej ramienia cząsteczki tRNA zaburzają silnie konserwowaną II rzędową strukturę tRNA ${ }^{\text {Ser(UCN) }}[32,77]$. Mutacje te zidentyfikowano wśród różnych członków rodzin $\mathrm{z}$ niedosłuchem izolowanym zarówno w postaci homo-, jak i heteroplazmatycznej, ale stopień heteroplazmii nie korelował ani z głębokością, ani wiekiem, w którym wystąpił niedosłuch [81,82].

Mutacja m.7511T >C została opisana w kilku rodzinach jako powodująca niedosłuch. Rodziny $\mathrm{z}$ tym wariantem pochodziły $\mathrm{z}$ różnych grup etnicznych $\mathrm{w}$ tym $\mathrm{z}$ Afryki [56], Francji [83] oraz Japonii [84]. Zauważono różny stopień ubytku słuchu w badanych rodzinach. Niedosłuch stwierdzono u 7 z 23 (30\%) osób z dziedziczeniem $\mathrm{w}$ linii matczynej w jednej z rodzin japońskich [85], 43\% i $30 \%$ w dwóch francuskich rodzinach [83], 67\% w kolejnej rodzinie japońskiej [86], aż 84\% w rodzinie afrykańskiej [55]. Ponieważ u niektórych osób z wykrytą mutacją m.7511T $>C$ obserwowano słuch w granicach normy, sama mutacja może nie być wystarczającym czynnikiem powodującym niedosłuch. Jest wysoce prawdopodobne, że inne czynniki, np. polimorfizmy i/lub zmiany w genomie jądrowym lub czynniki środowiskowe, mogą modulować fenotypową zmienność i penetrację mutacji wśród osób ze zmianą $\mathrm{m} .7511 \mathrm{~T}>\mathrm{C}[82,83]$. W przypadku tej zmiany zarówno procent penetracji, jak i poziom heteroplazmii nie jest skorelowany $\mathrm{z}$ nasileniem niedosłuchu. U pacjentów $\mathrm{z}$ badanych rodzin nie stwierdzono zawrotów głowy czy innych, charakterystycznych objawów zaburzeń mitochondrialnych, choć u czterech osób (jednej pochodzenia japońskiego i trzech pochodzenia afrykańskiego) zdiagnozowano cukrzycę [55,86]. Można jednak stwierdzić, iż mutacja m.7511T >C zazwyczaj powoduje izolowany niedosłuch bez towarzyszących objawów.

\section{Terapie genowe}

Niedosłuch może powodować izolację społeczną, depresję oraz obniżenie zdolności zawodowych. W związku $\mathrm{z}$ tym potrzeba zrozumienia mechanizmu działania słuchu i możliwości jego poprawy jest ogromna. Obecnie w Polsce oraz na świecie wdrożono, w większości przypadków skuteczne, leczenie ubytku słuchu za pomocą aparatów słuchowych i implantów ślimakowych [87]. Równolegle prowadzone są jednak badania nad opracowaniem leczenia przyczynowego niedosłuchu, opartego na terapii genowej lub terapii z użyciem komórek macierzystych [88].

Skuteczna terapia genowa bazuje na wprowadzeniu do komórek obcych kwasów nukleinowych (DNA lub RNA), wywierających określony efekt terapeutyczny, np. polegający na wymuszeniu produkcji białka kodowanego przez wprowadzony gen lub oddziaływaniu na ekspresję innych genów. Prowadzono próby znalezienia metody leczenia głuchoty typu DFNB1, której przyczyną są mutacje genu GJB2. Wykonywane in vitro doświadczenia przekonują, że transfer prawidłowego genu Gjb2 u myszy może odtworzyć działanie kanałów „gap junction” (połączenia szczelinowe) w komórkach podporowych ślimaka, poprawiając zdolność słyszenia [89]. W innym badaniu wykorzystano adeno-pochodny wirus (AAV) in vivo u myszy pozbawionych poprawnie działającego genu Gjb2 i zanotowano 
ekspresję koneksyny-26 w sieci komórek podporowych. Nie wiązało się to ze znaczącą poprawą słuchu, ale tego typu projekty są obiecujące i skłaniają do dalszych badań w tym kierunku [90].

Natomiast w dziedzinie terapii z użyciem komórek macierzystych prowadzone są testy mające na celu wytworzenie nowych komórek rzęsatych u ssaków, np. badanie polegające na przekształceniu endogennych komórek podporowych w komórki rzęsate, za pomocą kluczowych elementów regulacyjnych, takich jak czynnik transkrypcyjny komórek rzęsatych - ATOH1, niezbędny do prawidłowego różnicowania tych komórek. Takie próby transfekcji Atoh1 do mysich komórek ucha wewnętrznego przeprowadzono wiele lat temu [91,92], co zaowocowało wdrożeniem w USA badań klinicznych nad lekiem CGF166, rekombinowanym adenowirusem 5 (Ad5), wektorem zawierającym m.in. cDNA kodujący ludzki czynnik transkrypcji Hath1. CGF166 posiada również swoisty promotor, który ogranicza ekspresję genu atonalnego do komórek wspomagających ucha wewnętrznego. Badania zostały zatwierdzone przez amerykańską Agencję Żywności i Leków (US Food and Drug Administration, FDA) pod numerem NCT02132130.

Jednak żadna $\mathrm{z}$ terapii genowych nie jest nawet $\mathrm{w}$ fazie badań klinicznych w przypadku leczenia niedosłuchu wywołanego przez mutacje w mtDNA. Dysfunkcje mitochondrialne, z uwagi na niezwykłe zróżnicowanie biochemiczne wyrażające się różnorodnością fenotypową, często powodują jednocześnie zaburzenia $\mathrm{w}$ wielu narządach. Terapia zaburzeń mitochondrialnych jest ogromnym wyzwaniem, a obecnie możliwie jest jedynie leczenie objawowe, bazujące m.in. na specyficznej i niespecyficznej farmakoterapii, zaleceniach dietetycznych oraz unikaniu leków lub procedur mających szkodliwy wpływ na dane schorzenie. W przypadku zespołu MELAS terapia specyficzna obejmuje np. stosowanie leków adrenergicznych i serotoninergicznych w depresji [93], leków uspokajających w stanach nadmiernego pobudzenia, a jeżeli chodzi o niespecyficzną terapię lekami - np. podawanie koenzymu Q (CoQ) lub witaminy C $[94,95]$.

\section{Podsumowanie}

Mutacje mtDNA są ważną przyczyną chorób genetycznych, m.in. niedosłuchu. Zmienność kliniczna zaburzeń sprawia, że diagnozowanie pacjentów $\mathrm{z}$ chorobą spowodowaną przez mutacje $\mathrm{w}$ mtDNA jest prawdziwym wyzwaniem. Osiągnięcia w dziedzinie nauki i technologii ostatnich kilku lat pozwalają na badane mitochondriów w sposób bardziej szczegółowy. Występowanie zaburzeń mitochondrialnych zostało już udokumentowane w chorobach związanych $\mathrm{z}$ wiekiem. Uważa się, że takie zaburzenia mogą być również istotne w patogenezie niektórych nowotworów czy w regulacji odporności. Rozszyfrowanie wzajemnych relacji między procesami zachodzącymi w mitochondriach i jądrze będzie miało kluczowe znaczenie dla pełnego zrozumienia roli tych organelli w funkcjach komórkowych. Istotne będzie również dokładne poznanie roli mitochondriów w reakcji na bodźce środowiskowe, infekcje, procesy starzenia i wadliwe działanie komórek, co może pozwolić w przyszłości na zastosowanie nowego podejścia terapeutycznego i lepszego radzenia sobie z tak poważnymi schorzeniami.

Nadal jednak największym wyzwaniem pozostanie jak najlepsze przełożenie eksperymentalnej wiedzy i badań populacyjnych na leczenie konkretnego pacjenta zgłaszającego się z chorobą spowodowaną przez mutacje w mitochondrialnym DNA.

Publikacja powstała w związku z realizacją projektów: Grant NCN: 2011/03/D/NZ5/05592; Grant NCN: 2012/05/N/NZ5/02629; Zintegrowany system narzędzi do diagnostyki i telerehabilitacji schorzeń narządów zmystów (słuchu, wzroku, mowy, równowagi, smaku, powonienia)" wspólfinansowany przez Narodowe Centrum Badań i Rozwoju w ramach Programu STRATEGMED.

\section{Piśmiennictwo:}

1. Moeller MP. Early intervention and language development in children who are deaf and hard of hearing. Pediatrics, 2000; 106(3): E43.

2. Nelson HD, Bougatsos C, Nygren P. Universal newborn hearing screening: systematic review to update the 2001 US Preventive Services Task Force Recommendation. Pediatrics, 2008; 122(1): 266-76.

3. Egilmez OK, Kalcioglu MT. Genetics of Nonsyndromic Congenital Hearing Loss. Scientifica (Cairo), 2016; 7576064.

4. Taanman JW. The mitochondrial genome: structure, transcription, translation and replication. Biochim Biophys Acta, 1999; 1410(2): 103-23.

5. Mukhopadhyay A, Weiner H. Delivery of drugs and macromolecules to mitochondria. Adv Drug Deliv Rev, 2007; 59(8): 729-38.

6. Ivanova DG i Yankova TM. The free radical theory of aging in search of a strategy for increasing life span. Folia Med (Plovdiv), 2013; 55(1): 33-41.

7. Cali T, Ottolini D, Brini M. Mitochondrial $\mathrm{Ca}(2+)$ as a key regulator of mitochondrial activities. Adv Exp Med Biol, 2012; 942: 53-73.
8. Csordas G i Hajnoczky G. SR/ER-mitochondrial local communication: calcium and ROS. Biochim Biophys Acta, 2009; 1787(11): 1352-62.

9. Lopez MF, Kristal BS, Chernokalskaya E, Lazarev A, Shestopalov A, Bogdanova A i wsp. High-throughput profiling of the mitochondrial proteome using affinity fractionation and automation. Electrophoresis, 2000; 21(16): 3427-40.

10. Calvo SE, Clauser KR, Mootha VK. MitoCarta2.0: an updated inventory of mammalian mitochondrial proteins. Nucleic Acids Res, 2016; 44(D1): 1251-57.

11. Fischel-Ghodsian N. Mitochondrial deafness. Ear Hear, 2003; 24(4): 303-13.

12. Irwin JA, Saunier JL, Niederstätter H, Strouss KM, Sturk KA, Diegoli TM i wsp. Investigation of heteroplasmy in the human mitochondrial DNA control region: a synthesis of observations from more than 5000 global population samples. J Mol Evol, 2009; 68(5): 516-27.

13. Taylor RW, Turnbull DM. Mitochondrial DNA mutations in human disease. Nat Rev Genet, 2005; 6(5): 389-402. 
14. Cao L, Shitara H, Horii T, Nagao Y, Imai H, Abe K i wsp. The mitochondrial bottleneck occurs without reduction of mtDNA content in female mouse germ cells. Nat Genet, 2007; 39(3): 386-90.

15. Sena LA, Chandel NS. Physiological roles of mitochondrial reactive oxygen species. Mol Cell, 2012; 48(2): 158-67.

16. Sinha K, Das J, Pal PB, Sil PC. Oxidative stress: the mitochondria-dependent and mitochondria-independent pathways of apoptosis. Arch Toxicol, 2013; 87(7): 1157-80.

17. Pavlakis SG, Phillips PC, DiMauro S, De Vivo DC i Rowland LP. Mitochondrial myopathy, encephalopathy, lactic acidosis, and strokelike episodes: a distinctive clinical syndrome. Ann Neurol, 1984; 16(4): 481-88.

18. Iwanicka-Pronicka K, Pollak A, Skórka A, Lechowicz U, Korniszewski L, Westfal P i wsp. Audio profiles in mitochondrial deafness m.1555A $>\mathrm{G}$ and $\mathrm{m} .3243 \mathrm{~A}>\mathrm{G}$ show distinct differences. Med Sci Monit, 2015; 21: 694-700.

19. Iwanicka-Pronicka K, Pollak A, Skórka A, Lechowicz U, Pajdowska M, Furmanek M i wsp. Postlingual hearing loss as a mitochondrial 3243A $>\mathrm{G}$ mutation phenotype. PLoS One, 2012; 7(10): e44054

20. Finsterer J. Inherited mitochondrial disorders. Adv Exp Med Biol, 2012; 942: 187-213.

21. Vanniarajan A, Rajshekher GP, Joshi MB, Reddy AG, Singh L i Thangaraj K. Novel mitochondrial mutation in the ND4 gene associated with Leigh syndrome. Acta Neurol Scand, 2006; 114(5): 350-53.

22. Rötig A, Cormier V, Blanche S, Bonnefont JP, Ledeist F, Romero $\mathrm{N}$ i wsp. Pearson's marrow-pancreas syndrome. A multisystem mitochondrial disorder in infancy. J Clin Invest, 1990; 86(5): 1601-68.

23. Moraes CT, DiMauro S, Zeviani M, Lombes A, Shanske S, Miranda AF i wsp. Mitochondrial DNA deletions in progressive external ophthalmoplegia and Kearns-Sayre syndrome. N Engl J Med, 1989; 320(20): 1293-99.

24. Zeviani M, Moraes CT, DiMauro S, Nakase H, Bonilla E, Schon EA i wsp. Deletions of mitochondrial DNA in Kearns-Sayre syndrome. Neurology, 1998; 51(6): 1525-33.

25. Maiese K. New Insights for Oxidative Stress and Diabetes Mellitus. Oxid Med Cell Longev, 2015; 2015: 875961.

26. Thangaraj K, Joshi MB, Reddy AG, Rasalkar AA, Singh L. Sperm mitochondrial mutations as a cause of low sperm motility. J Androl, 2003; 24(3): 388-92.

27. Magner M, Kolarova H, Honzik T, Svandova I, Zeman J. Clinical manifestation of mitochondrial diseases. Dev Period Med, 2015; 19(4): 441-49.

28. Abi-Hachem RN, Zine, Van De Water TR. The injured cochlea as a target for inflammatory processes, initiation of cell death pathways and application of related otoprotectives strategies. Recent Pat CNS Drug Discov, 2010; 5(2): 147-63.

29. Nicotera TM, Hu BH, Henderson D. The caspase pathway in noise-induced apoptosis of the chinchilla cochlea. J Assoc Res Otolaryngol, 2003; 4(4): 466-77.

30. Ohlemiller KK, Wright JS, Dugan LL. Early elevation of cochlear reactive oxygen species following noise exposure. Audiol Neurootol, 1999; 4(5): 229-36.

31. Someya S, Prolla TA. Mitochondrial oxidative damage and apoptosis in age-related hearing loss. Mech Ageing Dev, 2010; 131(7-8): 480-86.

32. Kokotas H, Petersen MB, Willems PJ. Mitochondrial deafness. Clin Genet, 2007; 71(5): 379-91.

33. Guan MX. Molecular pathogenetic mechanism of maternally inherited deafness. Ann NY Acad Sci, 2004; 1011: 259-71.
34. Goto Y, Nonaka I, Horai S. A mutation in the tRNA(Leu)(UUR) gene associated with the MELAS subgroup of mitochondrial encephalomyopathies. Nature, 1990; 348(6302): 651-53.

35. van den Ouweland JM, Lemkes HH, Ruitenbeek W, Sandkuijl LA, de Vijlder MF, Struyvenberg PA i wsp. Mutation in mitochondrial tRNA(Leu)(UUR) gene in a large pedigree with maternally transmitted type II diabetes mellitus and deafness. Nat Genet, 1992. 1(5): 368-71.

36. Shoffner JM, Lott MT, Lezza AM, Seibel P, Ballinger SW i Wallace DC. Myoclonic epilepsy and ragged-red fiber disease (MERRF) is associated with a mitochondrial DNA tRNA(Lys) mutation. Cell, 1990; 61(6): 931-37.

37. Zeviani M, Muntoni F, Savarese N, Serra G, Tiranti V, Carrara F i wsp. A MERRF/MELAS overlap syndrome associated with a new point mutation in the mitochondrial DNA tRNA(Lys) gene. Eur J Hum Genet, 1993; 1(1): 80-87.

38. Kameoka K, Isotani H, Tanaka K, Azukari K, Fujimura Y, Shiota $\mathrm{Y}$ i wsp. Novel mitochondrial DNA mutation in tRNA(Lys) (8296A-->G) associated with diabetes. Biochem Biophys Res Commun, 1998; 245(2): 523-27.

39. Jaksch M, Klopstock T, Kurlemann G, Dorner M, Hofmann $\mathrm{S}$, Kleinle S i wsp. Progressive myoclonus epilepsy and mitochondrial myopathy associated with mutations in the tRNA(Ser(UCN)) gene. Ann Neurol, 1998; 44(4): 635-40.

40. Ballinger SW, Shoffner JM, Hedaya EV, Trounce I, Polak MA, Koontz DA i wsp. Maternally transmitted diabetes and deafness associated with a $10.4 \mathrm{~kb}$ mitochondrial DNA deletion. Nat Genet, 1992; 1(1): 11-15.

41. Hao H, Bonilla E, Manfredi G, DiMauro S, Moraes CT. Segregation patterns of a novel mutation in the mitochondrial tRNA glutamic acid gene associated with myopathy and diabetes mellitus. Am J Hum Genet, 1995; 56(5): 1017-25.

42. Prezant TR, Agapian JV, Bohlman MC, Bu X, Oztas S, Qiu WQ i wsp. Mitochondrial ribosomal RNA mutation associated with both antibiotic-induced and non-syndromic deafness. Nat Genet, 1993; 4(3): 289-94.

43. Usami S, Abe S, Kasai M, Shinkawa H, Moeller B, Kenyon JB i wsp. Genetic and clinical features of sensorineural hearing loss associated with the 1555 mitochondrial mutation. Laryngoscope, 1997; 107(4): 483-90.

44. Estivill X, Govea N, Barcelo E, Badenas C, Romero E, Moral L i wsp. Familial progressive sensorineural deafness is mainly due to the mtDNA A1555G mutation and is enhanced by treatment of aminoglycosides. Am J Hum Genet, 1998; 62(1): 27-35.

45. Zhao H, Li R, Wang Q, Yan Q, Deng JH, Han D i wsp. Maternally inherited aminoglycoside-induced and nonsyndromic deafness is associated with the novel C1494T mutation in the mitochondrial $12 \mathrm{~S}$ rRNA gene in a large Chinese family. Am J Hum Genet, 2004; 74(1): 139-52.

46. Bacino C, Prezant TR, Bu X, Fournier P, Fischel-Ghodsian N. Susceptibility mutations in the mitochondrial small ribosomal RNA gene in aminoglycoside induced deafness. Pharmacogenetics, 1995; 5(3): 165-72.

47. Casano RA, Johnson DF, Bykhovskaya Y, Torricelli F, Bigozzi M, Fischel-Ghodsian N. Inherited susceptibility to aminoglycoside ototoxicity: genetic heterogeneity and clinical implications. Am J Otolaryngol, 1999; 20(3): 151-56.

48. Reid FM, Vernham GA, Jacobs HT. A novel mitochondrial point mutation in a maternal pedigree with sensorineural deafness. Hum Mutat, 1994; 3(3): 243-47.

49. Fischel-Ghodsian N, Prezant TR, Fournier P, Stewart IA, Maw M. Mitochondrial mutation associated with nonsyndromic deafness. Am J Otolaryngol, 1995; 16(6): 403-38. 
50. Sevior KB, Hatamochi A, Stewart IA, Bykhovskaya Y, Allen-Powell DR, Fischel-Ghodsian N i wsp. Mitochondrial A7445G mutation in two pedigrees with palmoplantar keratoderma and deafness. Am J Med Genet, 1998; 75(2): 179-85.

51. Tiranti V, Chariot P, Carella F, Toscano A, Soliveri P, Girlanda $\mathrm{P}$ i wsp. Maternally inherited hearing loss, ataxia and myoclonus associated with a novel point mutation in mitochondrial tRNASer(UCN) gene. Hum Mol Genet, 1995; 4(8): 1421-27.

52. Jaksch M, Hofmann S, Kleinle S, Liechti-Gallati S, Pongratz DE, Müller-Höcker J i wsp. A systematic mutation screen of 10 nuclear and 25 mitochondrial candidate genes in 21 patients with cytochrome c oxidase (COX) deficiency shows tRNA(Ser) (UCN) mutations in a subgroup with syndromal encephalopathy. J Med Genet, 1998; 35(11): 895-900.

53. Schuelke M, Bakker M, Stoltenburg G, Sperner J i von Moers A. Epilepsia partialis continua associated with a homoplasmic mitochondrial tRNA(Ser(UCN)) mutation. Ann Neurol, 1998; 44(4): 700-4.

54. Hutchin TP, Parker MJ, Young ID, Davis AC, Pulleyn LJ, Deeble J i wsp. A novel mutation in the mitochondrial tRNA(Se$\mathrm{r}(\mathrm{UCN})$ ) gene in a family with non-syndromic sensorineural hearing impairment. J Med Genet, 2000; 37(9): 692-94.

55. Friedman RA, Bykhovskaya Y, Sue CM, DiMauro S, Bradley R, Fallis-Cunningham R i wsp. Maternally inherited nonsyndromic hearing loss. Am J Med Genet, 1999; 84(4): 369-72.

56. Sue CM, Tanji K, Hadjigeorgiou G, Andreu AL, Nishino I, Krishna S i wsp. Maternally inherited hearing loss in a large kindred with a novel T7511C mutation in the mitochondrial DNA tRNA(Ser(UCN)) gene. Neurology, 1999; 52(9): 1905-8.

57. Rizzi MD, Hirose K. Aminoglycoside ototoxicity. Curr Opin Otolaryngol Head Neck Surg, 2007; 15(5): 352-57.

58. Rybak LP i Ramkumar V. Ototoxicity. Kidney Int, 2007; 72(8): 931-35.

59. Rydzanicz M, Wróbel M, Pollak A, Gawecki W, Brauze D, Kostrzewska-Poczekaj M i wsp. Mutation analysis of mitochondrial 12S rRNA gene in Polish patients with non-syndromic and aminoglycoside-induced hearing loss. Biochem Biophys Res Commun, 2010; 395(1): 116-21.

60. Skarzyński H, Lorens A, Piotrowska A. A new method of partial deafness treatment. Med Sci Monit, 2003; 9(4): CS20-24.

61. Wang Q i Steyger PS. Trafficking of systemic fluorescent gentamicin into the cochlea and hair cells. J Assoc Res Otolaryngol, 2009; 10(2): 205-19.

62. Hobbie SN, Akshay S, Kalapala SK, Bruell CM, Shcherbakov D i Bottger EC.Genetic analysis of interactions with eukaryotic rRNA identify the mitoribosome as target in aminoglycoside ototoxicity. Proc Natl Acad Sci USA, 2008; 105(52): 20888-93.

63. Alharazneh A, Luk L, Huth M, Monfared A, Steyger PS, Cheng AG i wsp. Functional hair cell mechanotransducer channels are required for aminoglycoside ototoxicity. PLoS One, 2011; 6(7): e22347.

64. Rahman S, Ecob R, Costello H, Sweeney MG, Duncan AJ, Pearce $\mathrm{K} \mathrm{i}$ wsp. Hearing in 44-45 year olds with m.1555A>G, a genetic mutation predisposing to aminoglycoside-induced deafness: a population based cohort study. BMJ Open, 2012; 2: e000411.

65. Dehne N, Rauen U, de Groot H i Lautermann J. Involvement of the mitochondrial permeability transition in gentamicin ototoxicity. Hear Res, 2002; 169(1-2): 47-55.

66. Forge A, Li L. Apoptotic death of hair cells in mammalian vestibular sensory epithelia. Hear Res, 2000; 139(1-2): 97-115.

67. Cunningham LL, Cheng AG i Rubel EW. Caspase activation in hair cells of the mouse utricle exposed to neomycin. J Neurosci, 2002; 22(19): 8532-40.
68. Matsui JI, Gale JE, Warchol ME. Critical signaling events during the aminoglycoside-induced death of sensory hair cells in vitro. J Neurobiol, 2004; 61(2): 250-66.

69. Bottger EC. Mutant A1555G mitochondrial 12S rRNA and aminoglycoside susceptibility. Antimicrob Agents Chemother, 2010; 54(7): 3073-74; author reply 3074-75.

70. Neefs JM, Van de Peer Y, De Rijk P, Goris A i De Wachter R. Compilation of small ribosomal subunit RNA sequences. Nucleic Acids Res, 1991; 19(Suppl): 1987-2015.

71. Lu J, Li Z, Zhu Y, Yang A, Li R, Zheng J i wsp. Mitochondrial 12S rRNA variants in 1642 Han Chinese pediatric subjects with aminoglycoside-induced and nonsyndromic hearing loss. Mitochondrion, 2010; 10(4): 380-90.

72. Yoshida M, Shintani T, Hirao M, Himi T, Yamaguchi A, Kikuchi K i wsp. Aminoglycoside-induced hearing loss in a patient with the 961 mutation in mitochondrial DNA. ORL J Otorhinolaryngol Relat Spec, 2002; 64(3): 219-22.

73. Elstner M, Schmidt C, Zingler VC, Prokisch H, Bettecken T, Elson JL i wsp. Mitochondrial $12 \mathrm{~S}$ rRNA susceptibility mutations in aminoglycoside-associated and idiopathic bilateral vestibulopathy. Biochem Biophys Res Commun, 2008; 377(2): 379-83.

74. Dennerlein S, Rehling P. Human mitochondrial COX1 assembly into cytochrome c oxidase at a glance. J Cell Sci, 2015; 128(5): 833-37.

75. Fischel-Ghodsian N, Kopke RD, Ge X. Mitochondrial dysfunction in hearing loss. Mitochondrion, 2004; 4(5-6): 675-94.

76. Pandya A, Xia XJ, Erdenetungalag R, Amendola M, Landa B, Radnaabazar J i wsp. Heterogenous point mutations in the mitochondrial tRNA Ser(UCN) precursor coexisting with the A1555G mutation in deaf students from Mongolia. Am J Hum Genet, 1999; 65(6): 1803-36.

77. Ding Y, Leng J, Fan F, Xia B, Xu P. The role of mitochondrial DNA mutations in hearing loss. Biochem Genet, 2013; 51(78): 588-602.

78. Maasz A, Komlosi K, Hadzsiev K, Szabo Z, Willems PJ, Gerlinger I i wsp. Phenotypic variants of the deafness-associated mitochondrial DNA A7445G mutation. Curr Med Chem, 2008; 15(13): 1257-62

79. Levinger L, Jacobs $\mathrm{O}$ i James M. In vitro 3'-end endonucleolytic processing defect in a human mitochondrial tRNA(Ser(UCN)) precursor with the U7445C substitution, which causes non-syndromic deafness. Nucleic Acids Res, 2001; 29(21): 4334-40.

80. Rydzanicz M, Cywińska K, Wróbel M, Pollak A, Gawęcki W, Wojsyk-Banaszak I i wsp. The contribution of the mitochondrial COI/tRNA(Ser(UCN)) gene mutations to non-syndromic and aminoglycoside-induced hearing loss in Polish patients. Mol Genet Metab, 2011. 104(1-2): 153-59.

81. Li R, Greinwald JH Jr, Yang L, Choo DI, Wenstrup RJ, Guan MX. Molecular analysis of the mitochondrial 12S rRNA and tRNASer(UCN) genes in paediatric subjects with non-syndromic hearing loss. J Med Genet, 2004; 41(8): 615-20.

82. Li X, Fischel-Ghodsian N, Schwartz F, Yan Q, Friedman RA, Guan MX. Biochemical characterization of the mitochondrial tRNASer(UCN) T7511C mutation associated with nonsyndromic deafness. Nucleic Acids Res, 2004; 32(3): 867-77.

83. Chapiro E, Feldmann D, Denoyelle F, Sternberg D, Jardel C, Eliot MM i wsp. Two large French pedigrees with non syndromic sensorineural deafness and the mitochondrial DNA T7511C mutation: evidence for a modulatory factor. Eur J Hum Genet, 2002; 10(12): 851-56. 
84. Li R, Ishikawa K, Deng JH, Heman-Ackah S, Tamagawa Y, Yang L i wsp. Maternally inherited nonsyndromic hearing loss is associated with the T7511C mutation in the mitochondrial tRNASerUCN gene in a Japanese family. Biochem Biophys Res Commun, 2005; 328(1): 32-27.

85. Yamasoba T, Tsukuda K, Suzuki M. Isolated hearing loss associated with T7511C mutation in mitochondrial DNA. Acta Otolaryngol Suppl, 2007; 559: 13-18.

86. Ishikawa K, Tamagawa Y, Takahashi K, Kimura H, Kusakari J, Hara A i wsp. Nonsyndromic hearing loss caused by a mitochondrial T7511C mutation. Laryngoscope, 2002; $112(8 \mathrm{Pt}$ 1): 1494-99.

87. Skarzynski H, Lorens A, Dziendziel B, Skarzynski PH. Expanding pediatric cochlear implant candidacy: A case study of electro-natural stimulation (ENS) in partial deafness treatment. Int J Pediatr Otorhinolaryngol, 2015; 79(11): 1896-900.

88. Askew C, Rochat C, Pan B, Asai Y, Ahmed H, Child E i wsp. Tmc gene therapy restores auditory function in deaf mice. Sci Transl Med, 2015; 7(295): 295ra108.

89. Crispino G, Di Pasquale G, Scimemi P, Rodriguez L, Galindo Ramirez F, De Siati RD i wsp. BAAV mediated GJB2 gene transfer restores gap junction coupling in cochlear organotypic cultures from deaf Cx26Sox10Cre mice. PLoS One, 2011; 6(8): e23279.
90. Yu Q, Wang Y, Chang Q, Wang J, Gong S, Li H i wsp. Virally expressed connexin 26 restores gap junction function in the cochlea of conditional Gjb2 knockout mice. Gene Ther, 2014; 21(1): 71-80.

91. Yang SM, Chen W, Guo WW, Jia S, Sun JH, Liu HZ i wsp. Regeneration of stereocilia of hair cells by forced Atoh1 expression in the adult mammalian cochlea. PLoS One, 2012; 7(9): e46355.

92. Gubbels SP, Woessner DW, Mitchell JC, Ricci AJ i Brigande JV. Functional auditory hair cells produced in the mammalian cochlea by in utero gene transfer. Nature, 2008; 455(7212): $537-41$.

93. DiMauro S, Mancuso M. Mitochondrial diseases: therapeutic approaches. Biosci Rep, 2007. 27(1-3): 125-37.

94. KC S, Carcamo JM, Golde DW. Vitamin C enters mitochondria via facilitative glucose transporter 1 (Glut1) and confers mitochondrial protection against oxidative injury. FASEB J, 2005; 19(12): 1657-67.

95. Procaccio V, Bris C, Chao de la Barca JM, Oca F, Chevrollier A, Amati-Bonneau P i wsp. Perspectives of drug-based neuroprotection targeting mitochondria. Rev Neurol (Paris), 2014; 170(5): 390-400. 